Gibson, Stephen ORCID:

https://orcid.org/0000-0002-5648-7669 (2015) From representations to representing: On social representations and discursive-rhetorical psychology. In: The Cambridge handbook of social representations. Cambridge, Cambridge University Press, pp. 210-223

Downloaded from: http://ray.yorksj.ac.uk/id/eprint/604/

The version presented here may differ from the published version or version of record. If you intend to cite from the work you are advised to consult the publisher's version:

Research at York St John (RaY) is an institutional repository. It supports the principles of open access by making the research outputs of the University available in digital form. Copyright of the items stored in RaY reside with the authors and/or other copyright owners. Users may access full text items free of charge, and may download a copy for private study or non-commercial research. For further reuse terms, see licence terms governing individual outputs. Institutional Repository Policy Statement

\title{
RaY
}

Research at the University of York St John

For more information please contact RaY at ray@yorksj.ac.uk 
From representations to representing: On social representations and discursive-rhetorical psychology

Stephen Gibson (York St John University, UK)

To appear in: G. Sammut, E. Andreouli, G. Gaskell, \& J. Valsiner (Eds.), The Cambridge handbook of social representations. Cambridge: Cambridge University Press. 
From representations to representing: On social representations and discursive-rhetorical

$$
\text { psychology }^{\mathrm{i}}
$$

The present chapter focuses on active processes of representing, and does so by exploring the links between social representations theory, discourse analysis and rhetorical psychology. It is argued that the focus on action in discursive and rhetorical approaches provides a lens through which we might view how social representations are used in specific social settings. Equally, the focus of social representations theorists on the 'sedimentation' of cultural themes provides one possibility through which discursive and rhetorical psychologists might be able to combine a focus on the micro-interactional with the more diffuse cultural-historical processes that partially shape the objects of discourse. The details of such an approach are necessarily preliminary, but in the latter part of the chapter I will provide a brief empirical example in an attempt to sketch out some of the possibilities afforded by a combination of a concern with both historical and micro-interactional processes of social construction.

Social representations theory and discursive-rhetorical psychology (DRP) have much in common, such as the use of some form of constructionist epistemological meta-theory, and the variety of approaches encompassed by these broad umbrella terms. Social representations theory has diversified into distinct traditions such as Abric's (e.g. 2001) structural approach, Markova's (e.g. 2003) dialogical approach, and many others besides (e.g. Wagner \& Hayes, 2005; Jovchelovitch, 2007; Howarth, 2006). Similarly, DRP takes in a range of approaches from Parker's (1992) critical realist approach, to Potter and Edwards's (1992) avowedly relativist discursive psychology (see Edwards, Ashmore \& Potter, 1995) and Billig's (1996) rhetorical psychology. Indeed, the term DRP is preferred here precisely in order to capture this breadth, and is intended to afford the potential to draw on the insights of these traditions 
whilst recognising that there may sometimes be epistemological tensions as a result of any attempt at eclecticism.

Such problems also have the potential to arise in any attempt to suggest a rapprochement between DRP and SRT. However, with movement on both sides these may not be insurmountable. Indeed, while there is a well-established tradition of critical engagement between the two theories - largely stemming from discourse analytical critiques of SRT from the mid-1980s onwards (e.g. Billig, 1991, 1993; Gibson \& Noret, 2010; Litton \& Potter, 1985; McKinlay \& Potter, 1987; Potter, 1996a, 1996b; Potter \& Billig, 1992; Potter \& Litton, 1985; Potter \& Edwards, 1999; Potter \& Wetherell, 1987, 1998) - both SRT and DRP have developed in various ways since the height of these critical encounters. Notably, as Howarth (2006, p. 68) has argued, in SRT, there has been greater recognition that social representations 'are not static templates that we pull out of our cognitive schemas' but should instead 'be seen as alive and dynamic - existing only in the relational encounter, in the inbetween space we create in dialogue and negotiation with others.' There is thus clearly potential for some level of integration, but this is more likely with some varieties of DRP and SRT than others. Whereas Howarth's approach is close in many respects to forms of DRP which take a broader approach to discourse, others - such as the structural approach - are less amenable. Similarly, approaches to DRP which are aligned more closely with conversation analysis (CA) are less likely to be able to incorporate the level of cultural-historical analysis necessitated by a broader focus on social representations.

For CA-oriented approaches, the question of where discursive resources come from is often simply sidestepped, but it is argued here that these questions are crucial: How do discursive resources become sedimented into the cultural milieu? What is the cultural milieu if not the constant sound of ongoing human interaction? How can a view of reality being 
constructed anew in each social encounter be sustained in the face of the seeming necessity for some element of temporal continuity (Condor, 1996)?

The initial discursive critique of SRT emphasised the alternative concept of interpretative repertoires; yet despite the continued use of this concept by some DA researchers, it has been suggested by proponents of more CA-orientated approaches (e.g. Wooffitt, 2005) that the concept of interpretative repertoire is itself too vague and insufficiently grounded in detailed analysis of interaction. This creates something of a problem, for DRP needs some sort of a theory of cultural reproduction, in a way that it doesn't need a theory of psychology (in the traditional sense).

For DRP, agnosticism on the underlying concept of mind is a necessary and desirable position, but agnosticism on cultural processes is - in my view - simply not an option. DRP needs to answer the question, 'where does all this stuff come from?' If interpretative repertoires are no longer seen as adequate to do the job, then other conceptual tools are needed. Social representations may constitute one such tool, but for many they will themselves come with too much theoretical baggage to allow for successful integration with DRP. Trying to find common ground is therefore a challenging task, but one that is potentially made easier if we consider what I take to be the two key problems facing any such attempt to integrate the approaches: the problem of 'sedimentation' and the problem of discourse.

\section{The problem of 'sedimentation'}

Discursive-rhetorical psychologists are faced with a problem of explaining the longer term processes of construction that furnish interaction with the basic building blocks from which social objects are constructed in each separate social encounter. This problem can be illuminated by considering a critique of the use of interview methods in 
qualitative psychological research. Potter and Hepburn (2005) point out that one of the key problems with interviewing is that the interaction will inevitably be 'flooded' with social scientific categories and priorities. They suggest that:

The social science agenda is bound up with (although goes beyond) the categories that are used. These include the various more or less technical terms and descriptions that appear in interview questions and interview responses. This is a rather complicated topic as it may be quite hard to judge what terms are social scientific and what are not. ... However, as social representations researchers, Foucaultians and others have argued, everyday talk can involve a range of 'sedimentations' of earlier 'theoretical' notions as the languages of psychoanalysis, Marxism, symbolic interactions and so on become parts of people's everyday conversational currency.

(Potter \& Hepburn, 2005, p. 292)

Recent developments in DP have arguably moved it towards a position where the focus is almost exclusively on the local interactional accomplishment of phenomena, with limited attention to the ways in which the 'sedimentations' referred to by Potter and Hepburn come about. In the absence of such an account of sedimentation in DP, the analyst is compelled to look elsewhere, and Potter and Hepburn provide two such candidates in social representations theory and Focaultian analysis. Yet if DP researchers can point to the problem of sedimentation, why can this not be built into discursive theory and analysis? To fully understand, say, the way in which some stretch of discourse is put together, it is surely necessary to explore both its local interactional accomplishment and the extent to which the resources on which it draws have become culturally sedimented and available for 
mobilisation by speakers (Wetherell, 1998). For example, the DP project of re-specifying psychological terms as speakers' resources rather than as objects of investigation themselves with referents 'under the skull' has furnished a great many insights into how psychological business gets done in the course of everyday activities. The counterparts to this micro-social constructionist position, however, are the more broader-brushed constructionist approaches to psychological language developed by authors such as Danziger (1997) and Soyland (1994). For instance, Danziger has traced the historical construction of the psychological domain through the use of particular linguistic categories. It is through this approach that we can begin to appreciate, for example, how many terms that we now take for granted as referring to mental interiority used to refer to external, publically-accessible phenomena. One feature of the history of psychological language therefore, is a gradual interiorizing of that which was once physical and observable.

This necessarily demands a form of analysis which moves beyond the focus on local interactional accomplishment. As Elcheroth, Doise and Reicher (2011, p. 755) have recently argued,

In understanding how particular representations win out, we should look at the ways in which they are sedimented into collective practices and institutional facts. Looking at survey responses is not enough, nor is looking at "natural" discourse. In any case, ethnographic descriptions of collective rituals and routine practices allow us to broaden the interpretative context for "speech acts": They help to explain what is communicated by other vehicles than words, and they clarify what words allow people to do together.

Although Elcheroth et al's distinction between the discursive and the non-discursive is perhaps too straightforward, their focus chimes with the more extended conceptualization of 'discourse' afforded by approaches such as semiotics (see, e.g., Hall, 1997), and indeed with 
those varieties of DRP which incorporate a more ideological-historical level of analysis (e.g. Billig, 1995; Wetherell, 1998). Billig's (1995) analysis of the unnoticed national flags (both literal and metaphorical) providing the banal national framing of everyday activities is a particularly good example of how the analysis of 'collective rituals and routine practices' (Elcheroth et al, 2011, p. 755), extending beyond a narrow conceptualization of 'discourse', can provide insights into precisely these processes of sedimentation. This also highlights the extent to which such sedimentations perform identity-work, naturalizing some groups (e.g. 'national' groups), and - moreover - particular versions of those groups. These sedimentations should not be understood as overly constraining - the possibility of contestation is always present (Billig, 1996; Reicher \& Hopkins, 2001) - but they furnish social actors with a range of cultural resources on which they can draw.

A fully worked out DRP therefore needs both the focus on local interactional processes and a focus on broader cultural processes. In short, it needs a theory of social representation. Whether some version of SRT itself could ever successfully be integrated with DRP would, however, require a similar movement on the part of SRT towards resolving the problem of discourse.

\section{The problem of discourse}

The core of the discursive critique of SRT has been the observation that discursive processes have 'the anomalous position of being at the heart of SRT as the engine for the generation and refinement of representations, and yet being a topic which has received no analytic attention' (Potter \& Edwards, 1999, p. 449). Despite the varied responses to this critique from SRT researchers (e.g. de Rosa, 2006; Liu et al., 2010; Markova, 2000; Moscovici, 1985; Moscovici \& Markova, 1998; Räty \& Snellman, 1992a, 1992b; Wagner, 1998), there has been acknowledgment in some quarters that 'conflict and argumentation are 
still under-theorized within social representations theory' (Voelklein \& Howarth, 2005, p. 441). Edwards (2006, p. 41) has referred to the terrain of the discursive psychologist as being the 'rich surface of language and social interaction'. There is little doubt that the broad array of approaches captured here under the DRP umbrella have contributed to a radically different way of approaching the subject matter of psychology, and to the extent that psychological phenomena have been re-cast as fundamentally social objects, many have suggested that there is little need to return to the traditional concern with interiority associated with mainstream psychology. However, for social representations theorists the 'rich surface' in itself is not enough - to understand representational processes we must extend our theorising into the twin realms of the social group and individual cognition ${ }^{\text {ii }}$. Yet the discursive critique has emphasised that we are in no position to make these extensions until we have a firmer grasp on what is going on discursively, and that once we have achieved such a grasp we may find that further extension is in fact unnecessary. An essential element in any attempt at integration is therefore a movement away from traditional conceptions of cognition on the part of SRT. Indeed, with recent moves towards engaging with dialogicality in SRT (e.g. Howarth, 2006; Markova, 2000, 2003), there are signs that the centrality of cognition may not be as pronounced in some versions of SRT as has sometimes been the case. By adopting a constructionist position on the relationship between language and cognition, any distinction between SRT and DRP arguably becomes more a matter of emphasis than degree. A number of things would follow, one of which would be a clearer focus on representation-as-action, with the analytic focus being drawn towards the way in which representations are 'produced, performed and constructed in precisely the way they are for their role in activities' (Potter \& Edwards, 1999, p. 488). Potter and Edwards conceptualize action 'in terms of the enormous range of practical, technical and interpersonal tasks that people perform while living their relationships, doing their jobs, and engaging in varied cultural domains' (1999, p. 448). Such 
a focus is necessary to ensure that the dynamic conception of social representations espoused at the theoretical level is followed through empirically, and would also dovetail with the methodological techniques afforded by DRP.

Although in one sense SRT has a long tradition of concern with the functions of social representations (e.g. Lahlou, 2001; Jost \& Ignatow, 2001), it has typically not been concerned with the ways in which particular representations are constructed in particular contexts to perform particular actions. Billig's (2008a, 2011, 2013; see also Billig, 2008b) recent work on social psychological writing offers a clue as to how this may have come about. Billig suggests that the focus on the noun representation has led to a relative neglect of the active verb-form representing. Similarly, Voelklein and Howarth (2005, p. 447) have argued that the primary focus of SRT has been 'on the content and structure of a social representation as opposed to its function and broader societal implications'. They thus suggest that SRT research needs 'to examine what social representations $d o$ in social and political relations' (ibid. p. 448 , italics in original) - in other words, SRT requires a renewed focus on action, and it is here that DRP can make an important contribution.

\section{Social representations of history}

To illustrate how these arguments may be used to point the way to a different approach in areas of current research in SRT, I will now consider recent work on social representations of history (e.g. Liu, 1999; Liu et al., 2005, 2009; Madoglou, Melista \& LiarisHochhau, 2010; Paez et al., 2008; Pennebaker et al., 2006). Much of this work has adopted large-scale cross-cultural survey methodology to explore which people and events are seen as being the most important in world history. For example, Liu et al. (2005, p. 175) asked the following question of over 2000 participants spread across twelve territories: 'Imagine that you were giving a seminar on world history. What 7 events would you teach as the most 
important in world history? How positively or negatively do you regard each event?' They found that $41 \%$ of all events selected across the sample as a whole involved warfare - far greater than any other type of event. Moreover, they found that in all twelve samples, World War II was identified as the most important event in world history, with World War I being identified as the second most important in all but one (the French sample selected the French Revolution). These studies have been accompanied by a theoretical framework which appears to offer much promise in addressing issues of narrative, discourse and contestation (e.g. Liu \& Hilton, 2005; Liu \& László, 2007). For example, Liu and Hilton (2005, p. 537) argue that 'history provides us with narratives that tell us who we are, where we came from and where we should be going. It defines a trajectory which helps construct the essence of a group's identity, how it relates to other groups, and ascertains what its options are for facing present challenges'. They go on to suggest that 'while the main events and people that constitute lay representations of history tend to be uncontroversial, their meaning and relevance to current events is often highly contested' (p. 539).

Despite this emphasis on narrative and contestation, it is notable that there is often a striking under-emphasis on processes of argumentation and contestation in work adopting this approach. For instance, Liu and Hilton (2005) consider the varying responses of France, Germany and the United Kingdom to the September $11^{\text {th }} 2001$ attacks on the USA:

That the same challenge elicited such diverse reactions from three allies confronted with the same problem is not difficult to understand in the light of history: Britain's charter sees it as a world policeman with the US just as in 1941 when the two nations combined to defend democracy against Germany, Italy and Japan; France’s charter sees it as defending human rights, but as a nation resistant to Anglo-Saxon world hegemony; finally, Germany is in quest of a new charter that will allow it to define a 
'normal' role in the world without arousing historically grounded fears of German aggression both at home and abroad.

(Liu \& Hilton, 2005, p. 538)

As broad glosses of these three states' positions these characterisations may seem plausible enough, but problems arise when one attempts to unpack them. To use the UK as an example, Liu \& Hilton point out that 'Britain' was 'America's principal military ally and dispatched troops [to Afghanistan] almost immediately' (ibid.). Yet it is unclear precisely what type of entity 'Britain' actually is in this formulation. The decision to send troops was taken by political actors, but to what extent does 'Britain' in this instance incorporate the UK population? There is evidence to suggest that the wider public were not generally supportive of the actions taken by the UK Government (Miller, 2002), so to suggest that the decision to go to war simply reflects a view of 'Britain' as a 'world policeman' is rather problematic. What view of 'Britain' underscored the opposition to war, and how can this be consonant with the notion of a singular 'charter'? There is, I would suggest, an elision here between government policy and public opinion, and at a more conceptual level between 'Britain' as pertaining to a social identity and 'Britain' as a synecdoche for 'the British Government' (Condor, 2006; Gibson \& Condor, 2009).

Similarly, at the level of methodology, the continued reliance on survey technologies obscures the constructive and narrative work that generates social representations of history. Where discursive findings are cited, they tend to be used as a point of departure for scale development (e.g. Liu \& Sibley, 2009; Sibley et al., 2008). In this respect, studies in this tradition have largely taken processes of construction for granted as underpinning responses to survey measures, without ever really subjecting these constructive processes to analytic scrutiny. Fundamentally, this neglects the constructive work done by survey instruments 
themselves, a key insight of Potter and Wetherell's (1987) original statement of the discourse analytic position in social psychology. The arguments outlined above concerning representations and discursive action are therefore particularly applicable to this tradition of work, and as Tileagă (2009, pp. 350-1, italics in original) has noted, this 'highlights the importance of studying representations of history as situated social action and social practice. A discursive approach suggests treating representations of history not as something 'pregiven', but as in need of constitution.' In the remainder of this chapter I will briefly sketch an alternative DRP-informed approach to the analysis of social representations of history.

\section{History in action}

Rather than exploring what, in abstract terms, are seen as the most important events in world history, we might fruitfully address the issue of what, precisely, such events are important for. This leads to a focus on the uses of representations of history - to a focus on history in action.

To flesh out these arguments, I will now turn to an empirical example from a broader project examining a corpus of televised debates collected during the early months of 2003 in the run-up to the Iraq War (for a fuller outline of the dataset, see Gibson, 2012a). The data presented here are drawn from an analysis of the use of historical analogies in arguments concerning the Iraq War (Gibson, 2012c; for further analyses derived from this dataset, see Gibson, 2011, 2012a, b; for another discursive analysis of the use of historical analogies in the context of the Iraq War, see Burridge, 2005). The extract is from an episode of the British Broadcasting Corporation's (BBC) Question Time programme broadcast on $13^{\text {th }}$ February 2003. The format of Question Time involves an audience composed of members of the public putting questions on the significant issues of the day to a panel of politicians, journalists and other commentators. It is chaired by David Dimbleby, and at the time the 
present dataset was collected, was dominated by discussion of Iraq. In the following extract, we see a World War II analogy being mobilized by an audience member, with a panellist, Simon Thomas (a Member of Parliament for the Welsh nationalist Plaid Cymru party) then contesting it through the invocation of an alternative historical analogy (see appendix for an explanation of the transcription conventions used in the extract):

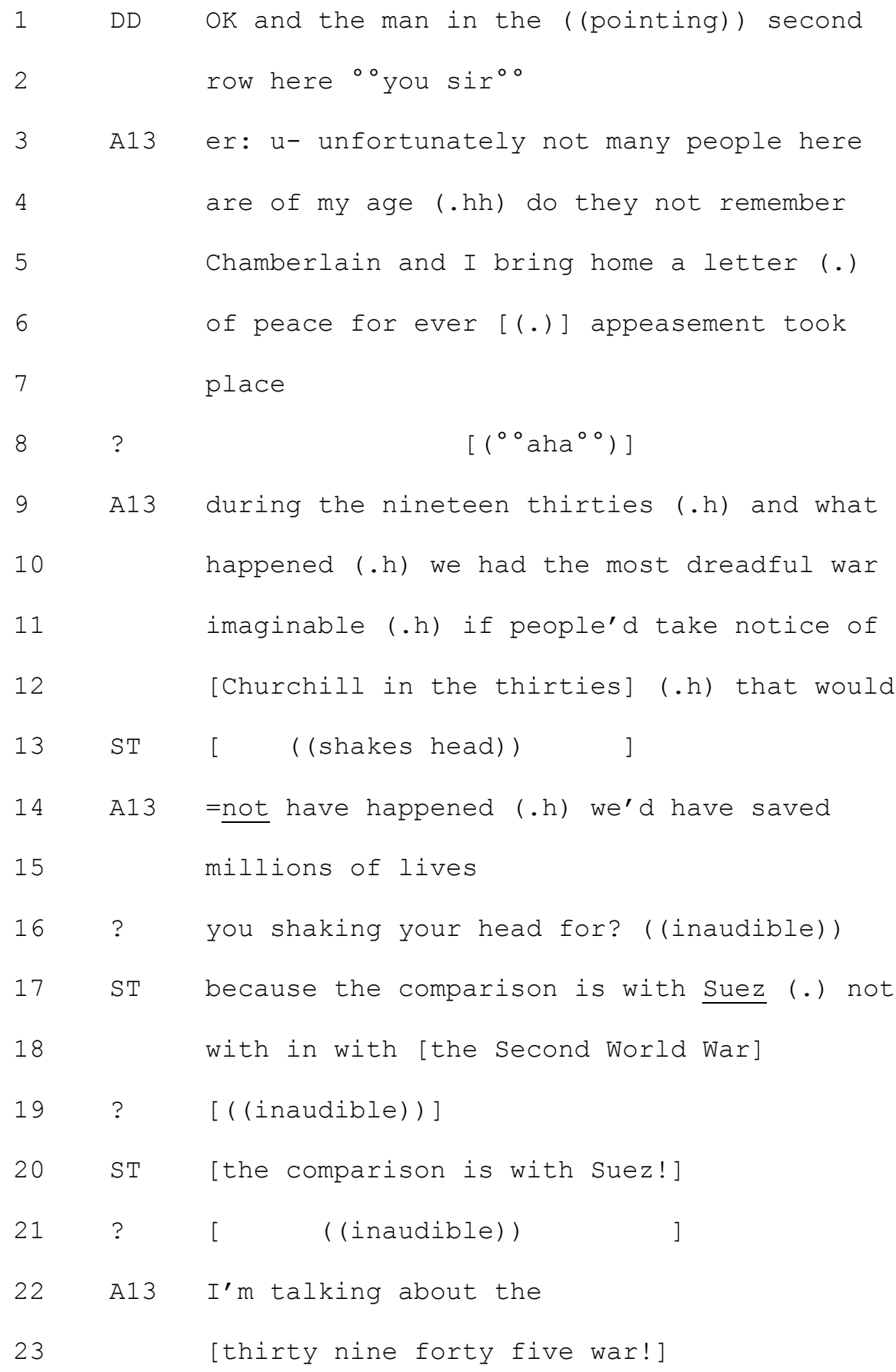




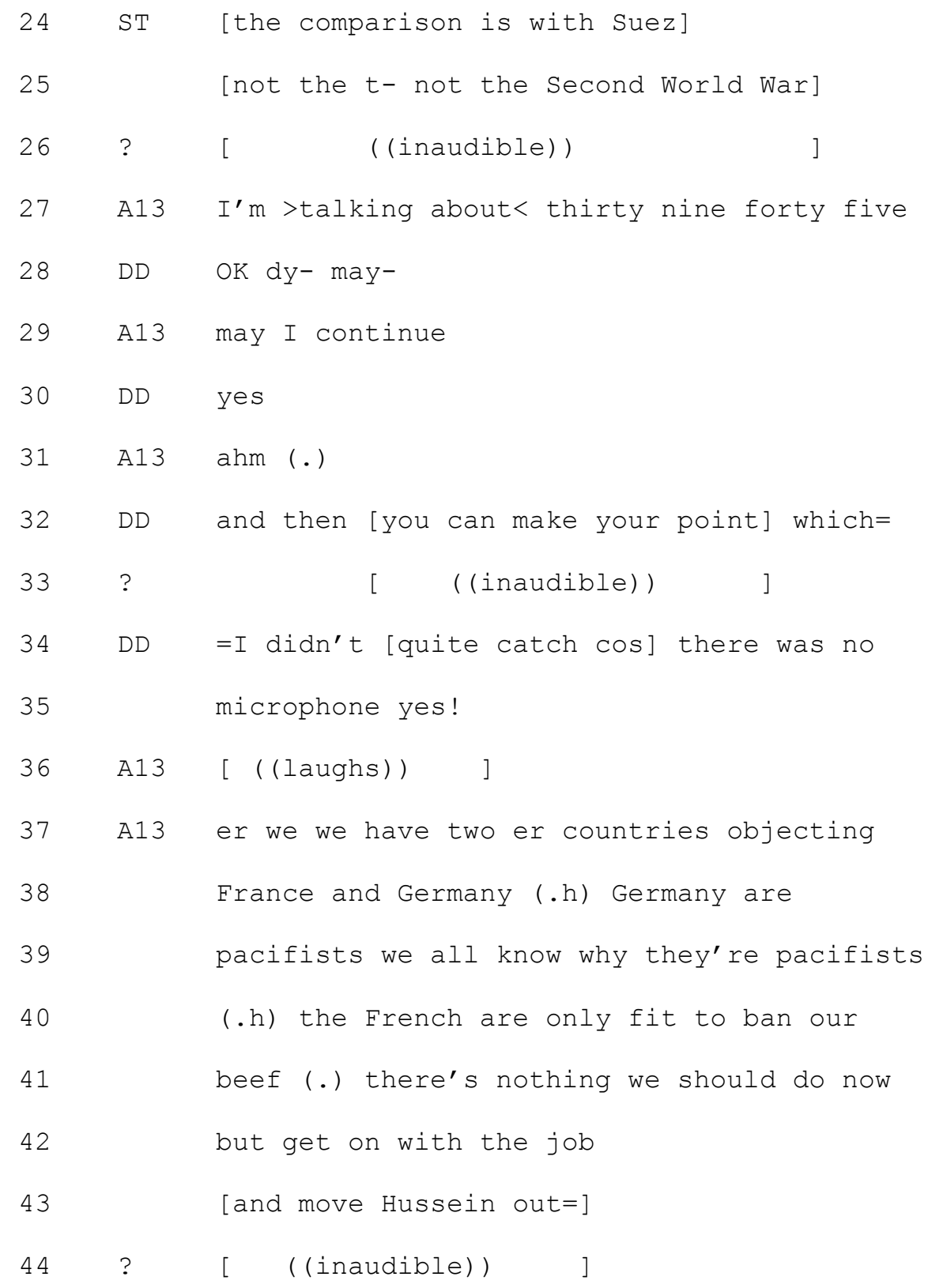

It is notable here that both historical analogies used in the extract - the Munich agreement of 1938 and the Suez crisis of 1956 - are invoked in ways which assume a shared understanding of the meaning and significance of the analogies. In constructing an analogy between World War II and the Iraq War, A13 uses category entitlement (Edwards \& Potter, 1992): 'unfortunately not many people here are of my age' (11. 3-4). He explicitly invokes memory in the question 'do they not remember Chamberlain' (11. 4-5), which, if taken literally, is oxymoronic - in addressing others as being younger than himself, he is positioning those 
others as specifically not having relevant first hand memories. His reference to remembering here can thus be understood as an exhortation to pay heed to a particular collective memory that should not be forgotten. He invokes the figure of Neville Chamberlain and paraphrases his infamous 1938 speech on returning from Munich (11. 5-6: 'I bring home a letter of peace for ever'). This active voicing (note the way in which the first person is used on line 5), coupled with the physical action of raising his hand in imitation of Chamberlain's holding aloft the piece of paper (see Figure 1), enables A13 not simply to invoke this event verbally, but to physically recreate it.

\section{INSERT FIGURE 1 HERE}

This reference to the policy of appeasement is then followed by a rhetorical question (11. 9-10: 'what happened'), which is used to construct a direct linkage between appeasement and 'the most dreadful war imaginable' (11. 10-11). A13 continues by invoking Churchill, and suggesting that had his warnings been heeded, 'millions of lives' would have been saved. The use of extreme case formulations (most dreadful, millions; see Pomerantz, 1986) works up the seriousness of the fate that awaits humanity if the mistakes of the past are repeated. It is notable that A13 invokes the failure to recognise the graveness of the situation in the 1930s: 'if people'd take notice of Churchill in the thirties' (11. 11-12). At this point, the screen cuts to Simon Thomas who can be seen shaking his head, and an unidentified member of the audience challenges him to explain this (1. 16). This challenge in itself highlights the difficulty of contesting the Munich analogy. Thomas's explanation involves contesting the relevance of World War II as a historical frame for the situation in Iraq, and he instead argues that 'the comparison is with Suez' (1. 17, 1. $20 \& 1.24)$. This is formulated as a straightforward matter of fact: no hedging or qualification is involved, and there is no 
attempt to mark the assertion as his opinion. This highlights the extent to which the audience is expected to understand what is meant by the invocation of 'Suez' - no additional information or explanation is required to explain the ways in which the present situation is analogous to the Suez crisis, it is simply treated as a collective memory which will resonate with the audience. Here, then, we have a speaker challenging the analogy between World War II and the Iraq War by invoking a conflict in which military intervention is generally understood to have been a mistake, and which ended in humiliation and the resignation of the then Prime Minister, Anthony Eden (for a history of the Suez crisis, see Kyle, 2011).

The role of the World War II analogy in A13's argument then becomes clear as he seeks to explain away the objections of France and Germany to military intervention in Iraq. The reference to common knowledge (1. 39: 'we all know') to explain German 'pacifism' again involves a more implicit invocation of World War II - albeit one that is perhaps made somewhat less implicit given the invocation of Chamberlain, Churchill and appeasement that preceded it. The crux of his argument is then reached, as he argues for 'get[ting] on with the job' and 'mov[ing] Hussein out' (11. 42-43).

We can understand this exchange as a contest over the most appropriate anchor for the situation in Iraq. This process should be understood as a rhetorical struggle over competing culturally-sedimented narratives (Billig, 1991; see also Lowe, 2012) - one of British national triumph in the face of initial reluctance to go to war, the other of British national humiliation as a result of undue haste in taking military action. It might be thus suggested that these narratives constitute good examples of social representations in the classical sense: they are consensually held narratives used for making the unfamiliar familiar. The sense-making function of the social representations of World War II and the Suez crisis can be seen quite clearly in the extent to which they are used in trying to frame the way in which the Iraq situation is to be understood. However, the sense-making function is only part of the story. 
People are not making sense of the Iraq situation in abstract terms, but are instead doing so as part of rhetorical projects aimed at making the case for or against military action. The social representation thus performs a discursive action within the context of its mobilization. This is in accordance with Howarth's (2006, p. 68) assertion that social representations should 'be seen as alive and dynamic - existing only in the relational encounter, in the in-between space we create in dialogue and negotiation with others.' It is only possible to fully draw out the implications of this, however, if analyses of social representations focus principally on the relational encounter, and for this the analytic tools and perspectives of DRP are indispensable.

Similarly, the suggestion that these social representations of history may be consensually held requires some clarification. One could, of course, conduct a survey to find out what meanings people associated with these events, but - as noted above - this would ride roughshod over the idea that social representations exist 'only in the relational encounter'. Instead, the conceptual and analytic toolkit of DRP can be drawn on to re-cast our understanding of the nature of consensus. Rather than an empirical question requiring some form of quantified answer to reassure ourselves that a social representation is indeed held by sufficient numbers of people to merit the description of it as being held consensually, we can treat such matters as participants' concerns. This avoids the retreat into cognitivism and methodological individualism associated with a survey-type approach which almost inevitably results in a picture of individuals carrying around social representations in their heads. Edwards (1997, p. 114) re-formulates such questions in terms of an approach to shared knowledge in which the analyst explores what participants' 'talk treats as shared, and when, and how' (emphasis in original). What is of interest is thus the way in which the speakers in the extract presented above mobilise the competing analogies in ways that treat them as consensual. 
This, however, is not enough on its own, and it is here that the need to explore the genealogy of the contents of discourse becomes important. Despite the roots of discursive psychology in (amongst other things) post-structuralist thought, discursive psychologists have arguably come to pay less attention to this key issue in more recent times. The crystallization of a conventional narrative of World War II as 'the good war' (Terkel, 1984) into a familiar cultural trope - a social representation - is, however, worthy of sustained attention.

In his impressive analysis of the creation of what he terms 'the pleasure culture of war' in British popular culture, Michael Paris (2000, p. 221) has argued that World War II 'has become, for the British people, a never ending story told and retold to remind themselves of a glorious past, in a far less glorious and depressing present.' With the decline of the UK's status as a significant world power following World War II, 'the nation preferred to look back to past military triumphs, in order to convince itself that Britain was still great. And the war which most epitomized the triumph of national spirit and moral certainty was, of course, the Second World War' (pp. 238-9). In this context, the Munich agreement, and the broader policy of appeasement which it represented, has come to be seen as deeply misguided, to say the least.

Despite enjoying widespread support at the time of the Munich agreement, the castigation of appeasement began very shortly afterwards. As Finney (2011, p. 194) has pointed out, this arose in no small part due to the ideological functions of such a critique of appeasement. Finney traces the historiography of appeasement to build a complex picture of how the dominant British image of World War II was developed and sustained. This process was already well underway during the war itself, as writers sought to construct accounts of the origins of the war which fulfilled the functions of both justifying military action, and engendering a sense of national unity. In particular, he points to the way in which the influential text Guilty Men, published pseudonymously as 'Cato' by Michael Foot, Frank 
Owen and Peter Howard in 1940, 'effected closure over other, more complex, explanations of the 1930s, by offering the only account which worked ideologically to provide a national history and present identity in tune with the new realities of the 'People's War'' (p. 194). As Finney's argument makes clear, in (re-)constructing these processes, we begin to see the relationship between representations of history and representations of identity. By furnishing a particular historical narrative, the conventionalized representation of the Munich agreement made it possible for the British to tell a particular kind of story about who 'we' are (see also Elcheroth, Doise \& Reicher, 2011; Liu \& Hilton, 2005).

However, this is not to say that such historical narratives are beyond contestation, both in terms of their historical accuracy (see Finney, 2011; Noon, 2004), and in terms of the general lessons that are to be drawn from them. In this latter respect, the Suez crisis arguably fulfils a similar role in the UK as does the Vietnam War in the USA (see e.g. Taylor \& Rourke, 1995). The narrative of national humiliation, the 'end of empire' (Kyle, 2011) and subsequent decline can be used to serve as a warning of the perils of military misadventures. As with Finney's analysis of Munich historiography, the concern is not with whether this view of the Suez crisis is accurate or not, but instead should be with the way in which a conventional narrative of the crisis crystallized, and the uses to which this narrative can be put.

\section{Concluding remarks}

The present chapter has argued that the potential for fruitful rapprochement between SRT and DRP can be developed by addressing the twin problems of discourse and sedimentation. If social representations theorists are confronted by problems concerning the appropriate incorporation of the discursive realm into their analytic schemas, discursiverhetorical psychologists are faced with the problem of explaining the provenance of cultural- 
discursive resources used by speakers/writers in any concrete setting. To be sure, these problems apply more to some variants of both approaches than to others, and the example outlined here should be seen as merely a preliminary step towards an integrated constructionist position. Nevertheless, the explanatory possibilities of seeking to build on existing attempts to combine micro and macro forms of social constructionism (e.g. Abell \& Stokoe, 2001; Wetherell, 1998) are potentially greater than either SRT or DRP, in their own right, are able to generate.

There may be reluctance amongst practitioners within both traditions to accept that in doing the type of work discussed here we are, in fact, studying social representations. It might be that terms such as 'collective memory', 'shared knowledge' or 'interpretative repertoire' are preferred. But we are dealing with the representation of something as socially shared, and there is already a term within social psychology's theoretical lexicon which captures the concept nicely: social representation. 


\section{References}

Abell, J., \& Stokoe, E. H. (2001). Broadcasting the royal role: Constructing culturally situated identities in the Princess Diana Panorama interview. British Journal of Social Psychology, 40, 417-435.

Abric, J.-C. (2001). A structural approach to social representations. In K. Deaux \& G. Philogène (Eds.), Representations of the social: Bridging theoretical traditions (pp. 42-47). Oxford: Blackwell.

Billig, M. (1991). Ideology and opinions: Studies in rhetorical psychology. London: Sage.

Billig, M. (1993). Studying the thinking society: Social representations, rhetoric, and attitudes. In G. M. Breakwell \& D. V. Canter (Eds.), Empirical approaches to social representations. Oxford: Oxford University Press.

Billig, M. (1995). Banal nationalism. London: Sage.

Billig, M. (1996). Arguing and thinking: A rhetorical approach to social psychology $\left(2^{\text {nd }}\right.$ ed.). Cambridge: Cambridge University Press.

Billig, M. (2008a). Social representations and repression: Examining the first formulations of Freud and Moscovici. Journal for the Theory of Social Behaviour, 38, 355-368.

Billig, M. (2008b). The language of critical discourse analysis: The case of nominalization. Discourse \& Society, 19, 783-800.

Billig, M. (2011). Writing social psychology: Fictional things and unpopulated texts. British Journal of Social Psychology, 50, 4-20.

Billig, M. (2013). Learn to write badly: How to succeed in the social sciences. Cambridge: Cambridge University Press.

Burridge, J. D. (2005). The construction of discursive difficulty: The circulation of, and resistance to, moral asymmetries in the public debate over the invasion of Iraq in 2003. (Doctoral thesis, University of Nottingham). Retrieved from http://etheses.nottingham.ac.uk/2390/1/416313.pdf 
Condor, S. (1996). Social identity and time. In W. P. Robinson (Ed.), Social groups and identities: Developing he legacy of Henri Tajfel (pp. 285-315). Oxford: Butterworth Heinemann.

Condor, S. (2006). Temporality and collectivity: Diversity, history and the rhetorical construction of national entitativity. British Journal of Social Psychology, 45, 657682.

Danziger, K. (1997). Naming the mind: How psychology found its language. London: Sage.

de Rosa, A. S. (2006). The "boomerang” effect of radicalism in discursive psychology: A critical overview of the controversy with the social representations theory. Journal for the Theory of Social Behaviour, 36, 161-201.

Edwards, D. (1997). Discourse and cognition. London: Sage.

Edwards, D. (2006). Discourse, cognition and social practices: The rich surface of social interaction. Discourse Studies, 8, 41-49.

Edwards, D., Ashmore, M., \& Potter, J. (1995). Death and furniture: The rhetoric, politics and theology of bottom line arguments against relativism. History of the Human Sciences, 8, 25-49.

Edwards, D., \& Potter, J. (1992). Discursive psychology. London: Sage.

Finney, P. (2011). Remembering the road to World War Two: International history, national identity, collective memory. Abingdon: Routledge.

Gibson, S. (2011). Social psychology, war and peace: Towards a critical discursive peace psychology. Social and Personality Psychology Compass, 5, 239-250.

Gibson, S. (2012a). 'I'm not a war monger but...': Discourse analysis and social psychological peace research. Journal of Community and Applied Social Psychology, $22,159-173$. 
Gibson, S. (2012b). Supporting the troops, serving the country: Rhetorical commonplaces in the representation of military service. In S. Gibson \& S. Mollan (Eds), Representations of peace and conflict. Basingstoke: Palgrave Macmillan.

Gibson, S. (2012c). History in action: The construction of historical analogies in televised debates concerning the Iraq War. Papers on Social Representations, 21, 13.1-13.35.

Gibson, S., \& Condor, S. (2009). State institutions and social identity: National representation in soldiers' and civilians' interview talk concerning military service. British Journal of Social Psychology, 48, 313-336.

Gibson, S., \& Noret, N. (2010). Historical experiences, collective memory, and willingness to fight for one's country: Comments on Paez et al. (2008). Journal of Cross-Cultural Psychology, 41, 445-450.

Elcheroth, G., Doise, W., \& Reicher, S. (2011). On the knowledge of politic and the politics of knowledge: How a social representations approach helps us rethink the subject of political psychology. Political Psychology, 32, 729-758.

Hall, S. (1997). Introduction. In S. Hall (ed.), Representation: Cultural representations and signifying practices. London: Sage.

Howarth, C. (2006). A social representation is not a quiet thing: Exploring the critical potential of social representations theory. British Journal of Social Psychology, 45, $65-86$.

Hutchby, I., \& Wooffitt, R. (1998). Conversation analysis: Principles, practices and applications. Cambridge: Polity.

Jefferson, G. (2004). Glossary of transcript symbols with an introduction. In G. H. Lerner (Ed.), Conversation analysis: Studies from the first generation (pp. 13-31). Amsterdam: John Benjamins. 
Jost, J. T., \& Ignatow, G. (2001). What we do and don't know about the functions of social representations. In K. Deaux \& G. Philogène (Eds.), Representations of the social: Bridging theoretical traditions (pp. 190-198). Oxford: Blackwell.

Jovchelovitch, S. (2007). Knowledge in context: Representations, community and culture. Hove: Routledge.

Kyle, K. (2011). Suez: Britain's end of empire in the Middle East (new ed.). London: I. B. Tauris.

Lahlou, S. (2001). Functional aspects of social representations. In K. Deaux \& G. Philogène (Eds.), Representations of the social: Bridging theoretical traditions (pp. 131-146). Oxford: Blackwell.

Litton, I., \& Potter, J. (1985). Social representations in the ordinary explanation of a 'riot'. European Journal of Social Psychology, 15, 371-388.

Liu, J. H. (1999). Social representations of history: Preliminary notes on content and consequences around the Pacific Rim. International Journal of Intercultural Relations, 23, 215-236.

Liu, J. H., Goldstein-Hawes, R., Hilton, D., Huang, L.-L., Gastardo-Conaco, C., DreslerHawke, E., ... Hidaka, Y. (2005). Social representations of events and people in world history across 12 cultures. Journal of Cross-Cultural Psychology, 36, 171-191.

Liu, J. H., \& Hilton, D. J. (2005). How the past weighs on the present: Social representations of history and their role in identity politics. British Journal of Social Psychology, 44, $537-556$.

Liu, J. H., \& László, J. (2007). A narrative theory of history and identity: Social identity, social representations, society and the individual. In G. Moloney \& I. Walker (Eds.), Social representations and identity: Content, process and power (pp. 85-107). Basingstoke: Palgrave Macmillan. 
Liu, J. H., Páez, D., Slawuta, P., Cabecinhas, R., Techio, E., Kokdemir, D., ... Zlobina, A. (2009). Representing world history in the $21^{\text {st }}$ century: The impact of $9 / 11$, the Iraq War, and the nation-state on dynamics of collective remembering. Journal of CrossCultural Psychology, 40, 667-692.

Liu, J. H., Paez, D., Techio, E., Slawuta, P., Zlobina, A., \& Cabecinhas, R. (2010). From gist of a wink to structural equivalence of meaning: Towards a cross-cultural psychology of the collective remembering of world history. Journal of Cross-Cultural Psychology, 41, 451-456.

Liu, J. H., \& Sibley, C. G. (2009). Culture, social representations, and peacemaking: A symbolic theory of history and identity. In C. J. Montiel \& N. M. Noor (Eds.), Peace psychology in Asia. New York: Springer.

Lowe, R. D. (2012). Temporality and identity: The role of time in the representation of social identities at political demonstrations. Papers on Social Representations, 21, 14.114.29.

Madoglou, A., Melista, A., \& Liaris-Hochhaus, S. (2010). Greeks' and Germans' representations of world events: Selective memory and voluntary oblivion. Papers on Social Representations, 19, 22.1-22.40.

Markova, I. (2000). Amédée or how to get rid of it: Social representations from a dialogical perspective. Culture \& Psychology, 6, 419-460.

Markova, I. (2003). Dialogicality and social representations: The dynamics of mind. Cambridge: Cambridge University Press.

McKinlay, A., \& Potter, J. (1987). Social representations: A conceptual critique. Journal for the Theory of Social Behaviour, 17, 471-487.

Miller, D. (2002). Opinion polls and the misrepresentation of public opinion on the war with Afghanistan. Television \& New Media, 3, 153-161. 
Moscovici, S. (1985). Comment on Potter \& Litton. British Journal of Social Psychology, 24, 91-92.

Moscovici, S., \&Markova, I. (1998). Presenting social representations: A conversation. Culture \& Psychology, 4, 371-410.

Noon, D. H. (2004). Operation enduring analogy: World War II, the war on terror, and the uses of historical memory. Rhetoric \& Public Affairs, 7, 339-364.

Paez, D., Liu, J. H., Techio, E., Slawuta, P., Zlobina, A., \& Cabecinha, R. (2008).

"Remembering" World War II and willingness to fight: Sociocultrual factors in the social representation of historical warfare across 22 societies. Journal of CrossCultural Psychology, 39, 373-380.

Paris, M. (2000). Warrior nation: Images of war in British popular culture, 1850-2000. London: Reaktion.

Parker, I. (1992). Discourse dynamics: Critical analysis for social and individual psychology. London: Routledge.

Pennebaker, J. W., Páez, D., Deschamps, J. C., Rentfrow, J., Davis, M., Techio, E. M., ... Zubieta, E. (2006). The social psychology of history: Defining the most important events of the last 10, 100, and 1000 years. Psicologia Politica, 32, 14-32.

Pomerantz, A. M. (1986). Extreme case formulations: A way of legitimizing claims. Human Studies, 9, 219-229.

Potter, J. (1996a). Representing reality: Discourse, rhetoric and social construction. London: Sage.

Potter, J. (1996b). Attitudes, social representations and discursive psychology. In M. Wetherell (Ed.), Identities, groups and social issues. London: Sage.

Potter, J., \& Billig, M. (1992). Re-representing representations - discussion of Räty \& Snellman. Ongoing Production on Social Representations, 1, 15-20. 
Potter, J., \& Edwards, D. (1999). Social representations and discursive psychology: From cognition to action. Culture \& Psychology, 5, 447-458.

Potter, A., \& Hepburn, A. (2005). Qualitative interviews in psychology: Problems and possibilities. Qualitative Research in Psychology, 2, 281-307.

Potter, J., \& Litton, I. (1985). Some problems underlying the theory of social representations. British Journal of Social Psychology, 24, 81-90.

Potter, J., \& Wetherell, M. (1987). Discourse and social psychology: Beyond attitudes and behaviour. London: Sage.

Potter, J., \& Wetherell, M. (1998). Social representations, discourse analysis, and racism. In U. Flick (Ed.), The psychology of the social (pp. 138-155). Cambridge: Cambridge University Press.

Räty, H., \& Snellman, L. (1992a). Making the unfamiliar familiar - some notes on the criticism of the theory of social representations. Ongoing Production on Social Representations, 1, 3-13.

Räty, H., \& Snellman, L. (1992b). Some further notes: Replies to Ibañez and Potter \& Billig. Ongoing Production on Social Representations, 1, 27-28.

Reicher, S., \& Hopkins, N. (2001). Self and nation. London: Sage.

Sibley, C. G., Liu, J. H., Duckitt, J., \& Khan, S. S. (2008). Social representations of history and the legitimation of social inequality: The form and function of historical negation. European Journal of Social Psychology, 38, 542-565.

Soyland, A. J. (1994). Psychology as metaphor. London: Sage.

Taylor, A. J., \& Rourke, J. T. (1995). Historical analogies in the Congressional foreign policy process. The Journal of Politics, 57, 460-468.

Terkel, S. (1984). The good war: An oral history of World War II. New York: The New Press. 
Tileagă, C. (2009). The social organization of representations of history: The textual accomplishment of coming to terms with the past. British Journal of Social Psychology, 48, 337-355.

Voelklein, C., \& Howarth, C. (2005). A review of controversies about social representations theory: A British debate. Culture \& Psychology, 11, 431-454.

Wagner, W. (1998). Social representations and beyond: Brute facts, symbolic coping and domesticated worlds. Culture \& Psychology, 4, 297-329.

Wagner, W., \& Hayes, N. (2005). Everyday discourse and common sense: The theory of social representations. Basingstoke: Palgrave.

Wetherell, M. (1998). Positioning and interpretative repertoires: Conversation analysis and post-structuralism in dialogue. Discourse and Society, 9, 387-412.

Wooffitt, R. (2005). Conversation analysis and discourse analysis: A comparative and critical introduction. London: Sage. 


\section{Appendix}

The transcription conventions (adapted from Hutchby \& Wooffitt, 1998, pp. vi-vii) used are listed below. These are a slightly simplified form of the Jeffersonian transcription conventions (Jefferson, 2004) favoured by conversation analysts and many discursive psychologists, and are particularly useful for capturing the finer details of talk.

(1.0) The number in parentheses indicates a time gap to the nearest tenth of a second.

(.) A dot enclosed in parentheses indicates a pause in the talk of less than two-tenths of a second.

[ ] Square brackets between adjacent lines of concurrent speech indicate the onset and end of a spate of overlapping talk.

.hh A dot before an ' $h$ ' indicates speaker in-breath. The more h's, the longer the in-breath

hh An ' $h$ ' indicates an out-breath. The more h's, the longer the breath.

(( )) A description enclosed in double parentheses indicates a non-verbal activity. For example, ((pointing)). Alternatively double parentheses may enclose the transcriber's comments on contextual or other features.

- $\quad$ A dash indicates the sharp cut-off of the prior word or sound.

: $\quad$ Colons indicate that the speaker has stretched the preceding sound. The more colons the greater the extent of stretching.

! Exclamation marks are used to indicate an animated or emphatic tone.

that Underlined fragments indicate speaker emphasis.

$\circ \circ$ Degree signs are used to indicate that the talk they encompass is spoken noticeably quieter than the surrounding talk.

$>\quad$ 'More than' and 'less than' signs indicate that the talk they encompass was produced noticeably quicker than the surrounding talk. 
Speaker identification: DD = David Dimbleby (Host); ST $=$ Simon Thomas MP (on-screen caption: Plaid Cymru). Audience members are identified by the letter 'A' followed by a numeral which indicates the order in which they responded in the discussion of Iraq in any given programme. Collective audience responses (e.g. applause) are identified by 'Au'. Unidentified speakers are indicated with a '?'. 
Figure

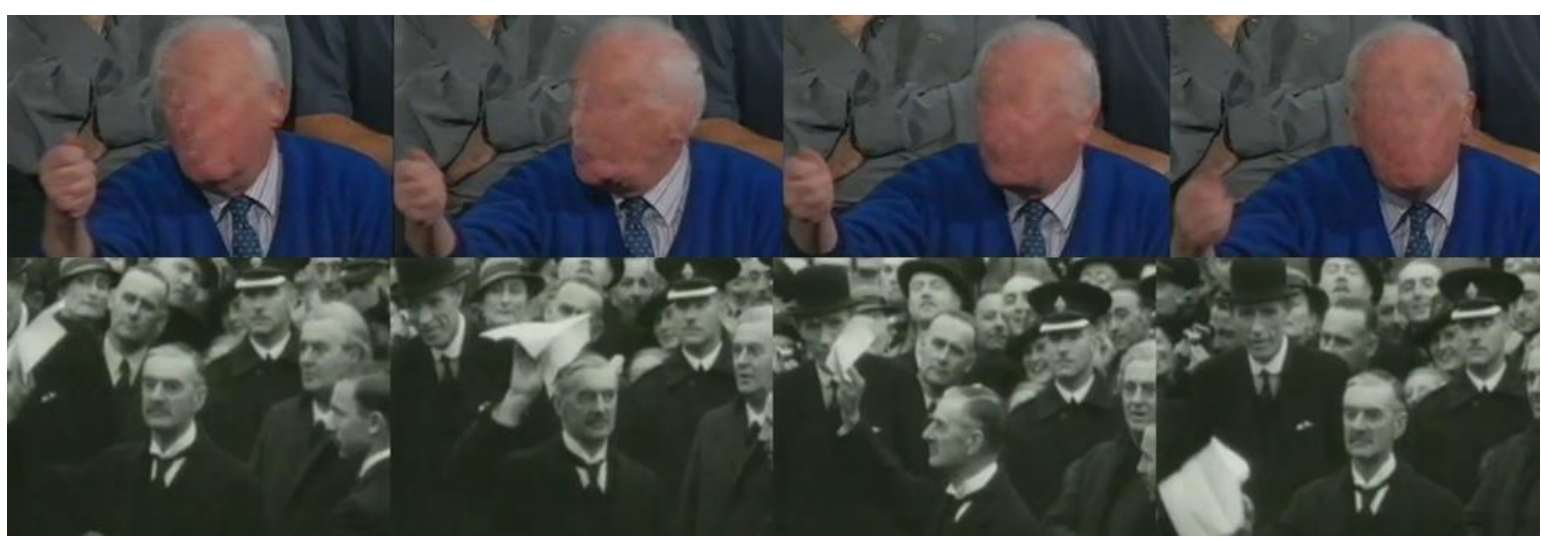

Figure 1. Physical representation of Chamberlain's waving gesture by A13 (corresponding to $11.5-6$ in the extract $)^{\mathrm{iii}}$, with Chamberlain's original gesture $\left(30^{\text {th }}\right.$ September 1938 ; from http://www.youtube.com/watch?v=FO725Hbzfls). 


\section{Footnotes}

\footnotetext{
${ }^{\mathrm{i}}$ This chapter is a development and extension of ideas first presented in 'History in action: The construction of historical analogies in televised debates concerning the Iraq War', published in Papers on Social Representations (2012, vol. 21, pp. 13.1-13.35). I am grateful to the London School of Economics \& Political Science, publisher of Papers on Social Representations, for allowing me to reproduce some material from the earlier paper in the present chapter.

ii This rather broad characterization necessarily obscures differences in emphasis between approaches, but all varieties of SRT arguably feature this tripartite concern with cognition, language and groups.

${ }^{\text {iii }}$ Note that although the debate was televised and thus in the public domain, A13's face has been obscured in recognition of the different status of members of the public who participate as audience members, and public figures who comprise the panel.
} 